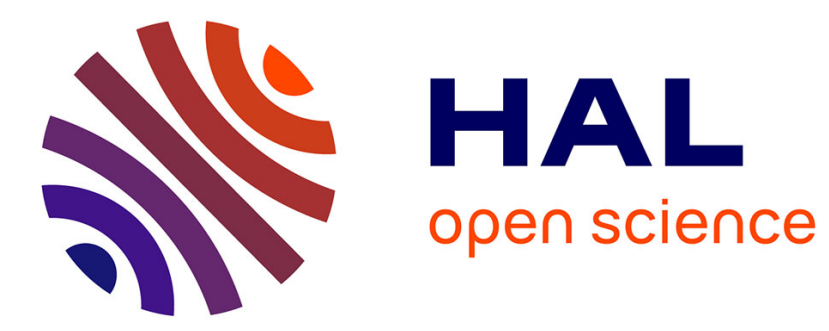

\title{
Migration from French Overseas Departments to Metropolitan France: What we can learn about a state policy from the censuses, 1962-1999
}

Marine Haddad

\section{- To cite this version:}

Marine Haddad. Migration from French Overseas Departments to Metropolitan France: What we can learn about a state policy from the censuses, 1962-1999. Population (English edition), 2018, 73 (2), pp.181-216. 10.3917/pope.1802.0181 . hal-02365921

\section{HAL Id: hal-02365921 \\ https://hal.science/hal-02365921}

Submitted on 15 Nov 2019

HAL is a multi-disciplinary open access archive for the deposit and dissemination of scientific research documents, whether they are published or not. The documents may come from teaching and research institutions in France or abroad, or from public or private research centers.
L'archive ouverte pluridisciplinaire HAL, est destinée au dépôt et à la diffusion de documents scientifiques de niveau recherche, publiés ou non, émanant des établissements d'enseignement et de recherche français ou étrangers, des laboratoires publics ou privés. 


\title{
Migration from French Overseas Departments to Metropolitan France: What We Can Learn about a State Policy from the Censuses, 1962-1999
}

\begin{abstract}
A word from the jury president
A total of 17 articles entered this year's competition for the Young Author's Prize organized by Population. Most of the papers received were considered to be of good quality. The texts were very varied, reflecting the most important current problems in population studies and the diverse centres of interest of young researchers around the world. Authors from four continents - Europe, Africa, Asia, and America - submitted a total of eight articles in English and nine in French. This shows the strong influence of the journal in the Englishspeaking world. Out of the 17 papers, seven were written by men and ten by women. Many of the themes correspond to the traditional areas of demography: mortality, fertility, nuptiality, and migration. However, the fields of interest have been extended to morbidity, religion, reproductive health, youth, gender violence, among others. The papers show the use of modern and powerful statistical techniques applied to demography, and many of them combine quantitative and qualitative approaches.

The third edition of the Young Author's Prize was organized as follows. Following an initial round of assessment, each of the remaining six articles was sent to two external reviewers. The jury members then examined all the articles and the reviewers' reports. The winner was selected at a final meeting on 5 February 2018.

On behalf of the jury, I would like to congratulate the winner, Marine Haddad, for her article: "Migration from French Overseas Departments to Metropolitan France: What We Can Learn about a State Policy from
\end{abstract}


the Censuses, 1962-1999". Marine Haddad is currently a PhD student in sociology at Sciences Po, Observatoire sociologique du changement. Using data from population censuses conducted between 1962 and 1999, her paper examines the effect of public policies on migration between metropolitan France and the overseas départements (DOM). She shows that the Office for DOM Migration (Bureau pour le développement des migrations dans les départements d'outre-mer, Bumidom) accelerated the growth in migration flows over the period, leading to a widening of the socioeconomic differences between the DOMs and metropolitan France.

This is a clearly presented, well-written paper, and I hope you will enjoy reading the article by the 2018 prize winner.

Manuel ORDORICA MELLADO

\section{Composition of the jury}

The jury of the third edition of the Young Author's Prize was chaired by Manuel Ordorica Mellado (El Colegio de México) and was composed of Carlo-Giovani Camarda (INED, Paris, France), Christophe Guilmoto (CEPED/IRD, France), Karel Neels (University of Antwerp, Belgium), and Aline Désesquelles (INED, Paris, France) as voting members, and Olivia Samuel (Université de Versailles Saint-Quentin, France) and Anne Solaz (INED, Paris, France) as non-voting members. 


\section{Migration from French Overseas Departments to Metropolitan France: What We Can Learn about a State Policy from the Censuses, 1962-1999}

In the post-war period, the French government implemented population control measures targeting the French overseas departments (départements d'outre-mer, or DOMs), where the rapid population growth was perceived as a public problem. ${ }^{(1)}$ During the 1950 s and 1960s, increasing numbers of violent strikes, riots, and altercations occurred between the police and the local populations (Constant, 1987; Daily, 2014; Stora, 2016). This social unrest was interpreted as the product of "relative overpopulation", and the battle against the "population explosion" became a key focus of the public authorities (Domenach and Picouet, 1992, pp. 82-83). Antinatalist policies intended to slow the increasing birth rate, while migration policies, epitomized by the actions of the Office for DOM Migration (Bureau pour la migration des DOM, or Bumidom) between 1963 and 1981, aimed to direct what was considered the population "excess" towards metropolitan France (mainland France and Corsica). By encouraging this mobility, the authorities also aimed to address the labour shortage in metropolitan France, which was experiencing a period of strong economic growth. During the 1970s, the protests of DOM militants opposed to the emigration policies grew more urgent; metropolitan France faced an economic slowdown and a rising unemployment rate. As a result of this new socioeconomic context, from 1981 onwards the government's migration measures changed drastically, as did the flows of migrants into metropolitan France. Even today, the role of the Bumidom remains a controversial subject: in the public arena, opinions are divided between criticism of it and support for the positive effects of migration in terms of upward mobility; in the scientific arena, the evaluation of its effects on migration flows is proving complex.

(1) French Guiana (hereafter: Guiana), Guadeloupe, Martinique, and Réunion are four former French colonies - located, respectively, north of Brazil, in the Caribbean, and south of Madagascar that became French overseas departments in 1946.

* Observatoire sociologique du changement (Sciences Po, Paris) and Laboratoire de sociologie quantitative (Center for Economic Research and Statistics)

Correspondence: Marine Haddad, CREST, Laboratoire de Sociologie Quantitative, 5 avenue Henry Le Chatelier, TSA 96642, 91764 Palaiseau CEDEX, France - Email: Marine.Haddad@ensae-paristech.fr DOI: $10.3917 /$ pope.1802.0181 
Based on a long-term analysis and comparison of the DOMs, this article aims to untangle the effect of state policies from the effects of the changing socioeconomic context. Was the Bumidom responsible for the boom in migration flows from the DOMs in the 1960s? Have political and economic developments since the 1980s changed the structure of these flows?

Using various complementary statistical approaches, this article looks at the changes in migration flows, not only in terms of size but also population structure. It relates these flows to changes in the organizations responsible for controlling DOM emigration and the labour market, using population censuses between 1968 and 1999. Part I of the article looks back on the establishment and political management of the overseas departments. The significance of the population transformations in the DOMs and of the migration policies gives rise to various hypotheses on the evolution of DOM-metropolitan France flows. To test these hypotheses, the article addresses several methodological challenges, including how to take migration selectivity into account. These challenges are explained in Part II. Part III of the article looks first at the effect of the Bumidom on the volume of migrations with respect to various dimensions (number of migrants, proportion of population, temporality of migrations). It uses the situation in Guiana as a counterfactual scenario and evaluates the effect of the Bumidom on population flows, using difference-in-differences regression. After assessing the catalytic effect of the Bumidom, which, in combination with other factors, massively increased emigration volumes, the third section focuses on the changes associated with the closure of the Bumidom and the deterioration of the economic context. The article then analyses the selectivity and the effect of migration in terms of educational levels over time.

\section{The demographics of overseas territories: a policy issue}

\section{The Antilles, Guiana, and Réunion: a common trajectory despite differing contexts}

From the seventeenth century, Guiana, Guadeloupe, Martinique, and Réunion were occupied by the French. Having been occupied for so long, these territories are known as the "old colonies" of France and have a specific place in colonial and postcolonial politics. When the French arrived, the few indigenous populations were decimated by war and disease. ${ }^{(2)}$ These "manufactured societies" (Waters, 2001) were then shaped by the system of slavery. The installation of large landowners and colonial administrators was accompanied by the forced displacement of slaves from various regions of sub-Saharan Africa. When slavery was abolished in 1848, former slaves legally became citizens. The speed with which this measure was implemented varied, but by the end of the nineteenth

(2) In Guiana, an Amerindian population survived but, living in the Amazon rainforest, was largely ignored by the colonial authorities. In Réunion, no indigenous population existed. 
century, everyone born in the Antilles, Guiana, and Réunion had French citizenship. In 1946, these regions became departments of France, rather than pursuing independence. Départementalisation was a key moment in the history of these regions and in their relationship with migration (Guyon, 2016; Temporal, 2011). It addressed a pressing need for integration, among both the political elite and local populations. The latter were hoping to obtain the equalization of social and legal conditions, based on the system operating in metropolitan France. But becoming a department strengthened the dependencies produced by colonization and created new ones (Crusol, 1975): it increased the metropolitan centralization of the territories' political and administrative authorities, the orientation of their resources and markets towards metropolitan France, and their financial dependence. ${ }^{(3)}$ Although the "departmentalization law" of 1946 stipulated equal rights across metropolitan France and the DOMs, the administrative system was slow to adapt, and social structures perpetuated severe inequalities (Dumont, 2010). ${ }^{(4)}$ By grouping them together under the administrative category départements d'outre-mer, this law enshrined the common political treatment of four former colonies that, despite their different geographical situations (Figure 1) and their own identities, share social structures built on a similar colonial background.

Figure 1. The overseas departments (DOMs) in 1961

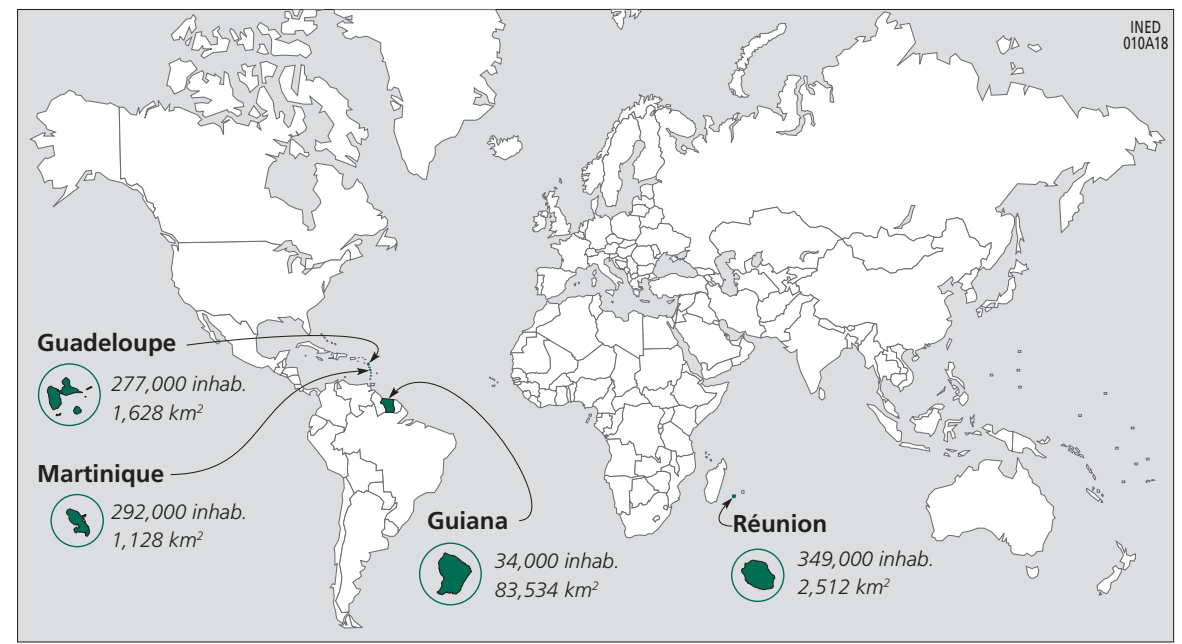

Source: Population census (INSEE).

Martinique and Guadeloupe are the two most similar departments: these islands of the Antilles share a strong Caribbean identity, and their populations are marked by inequalities between békés (whites who control the majority of wealth, often descendants of plantation owners) and black Antilleans and métisses. They have experienced waves of migration separate from the DOM-metropolitan

(3) Related to local budget deficits and inflation.

(4) In the first few years following departmentalization, colonial law was still sometimes applied. 
France flow (such as Indian immigration in the late nineteenth century and an influx of Syrians and Lebanese in the early twentieth century) but to more limited extents than Réunion and Guiana. The island of Réunion is the department situated farthest from metropolitan France. It stands out for its special relationship with the neighbouring island of Madagascar (a former French colony) and for its significant communities of Indian and Chinese immigrants dating from the nineteenth century. Binary (white/black) racial relations inherited from the time of slavery have been softened there by the presence of these diverse diasporas and of yabs (Pourchez, 2014). ${ }^{(5)}$ The accelerated expansion of the tertiary sector from the post-war period onwards, without being preceded by an industrialization phase, has created a labour market that persistently disadvantages the least educated Réunionese (Widmer, 1999).

Guiana is the only continental DOM, straddling South America and the Caribbean. Whereas the three island departments are characterized by demographic pressure associated with population growth within a limited territory, Guiana is a large and sparsely populated region. Until the post-war period, numerous attempts to increase the population had all failed (Maison and Millet, 1974). It is also the DOM with the highest levels of immigration proportional to the population since the 1970s (particularly from Haiti and Suriname). ${ }^{(6)}$ It may therefore seem surprising to expect the migration dynamics of Guianese to be similar to those of Antilleans and Réunionese. However, although its overall population density is low, in certain areas Guiana is affected by overpopulation (Domenach and Picouet, 1988). In 1982, two-thirds of the population lived in less than $0.2 \%$ of the land area (the island of Cayenne). The structure of the labour market and working conditions, characterized by a high level of unemployment and underemployment, are similar to those of the three other DOMs (Domenach and Guengant, 1981). As a result, the combination of strong demographic pressure and a tense social context exists in Guiana just as it does in the Antilles and Réunion. Migration towards metropolitan France is likely to provide a solution to unemployment and social conflict, with the same issues relating to geographical distance, the cost of migration, and racism, ${ }^{(7)}$ as well as with the same options relating to citizenship and territorial continuity with metropolitan France (for example, welfare transfers or access to financial support for mobility).

\section{Populations to be contained}

While a post-war drop in fertility in metropolitan France gave the authorities cause for concern, the strong population growth in the DOMs was perceived

(5) Yabs are descendants of white settlers, who became impoverished after the abolition of slavery; they are perceived very differently from very wealthy whites.

(6) At the 1982 census, 23\% of the population were foreign-born.

(7) Since the first Antilleans immigrated to metropolitan France, these migrants have experienced negative behaviour related to their skin colour (Daily, 2014). 
as a problem there (Domenach and Picouet, 1992), justifying different policies. In the 1960s, forced abortions and sterilizations took place in Réunion, with the complicity of the French authorities (Vergès, 2017). The child benefits system is limited in the DOMs: the amount of family allowance is lower than that available in metropolitan France and does not include any childbirth allowance or single-wage benefit. ${ }^{(8)}$ In 1968 , the Neuwirth law, which authorizes the sale of contraceptive products, was adapted to take into account the "special situation" in the DOMs (Article 6). Whereas all antinatalist promotion is prohibited in metropolitan France, such campaigns are used in the DOMs, particularly in Réunion (Maison and Millet, 1974). The contradiction between overseas and metropolitan policies reveals the persistence of colonial and even racist interactions, within which French citizens are treated differently depending on their place of birth (Childers, 2009; Vergès, 2017). Beginning in the 1960s, fertility fell rapidly in the DOMs, albeit a little later in Guiana. Between 1965 and 1989, it fell from 5.7 to 2.1 children per woman in the Antilles, and from 6.7 to 2.6 children in Réunion. However, the birth rate remained very high until the 1990s: between 1982-1990, it was 21 per 1,000 as opposed to 16 per 1,000 in metropolitan France (Cueugniet, 1991). Emigration policies formed part of this management of overseas populations. Their aim was to redirect what was perceived as excess population towards territories where it could be assimilated.

The first waves of emigration out of the DOMs began in the early twentieth century, when strong competition in the sugar cane market destabilized the already precarious socioeconomic conditions. It mainly consisted of emigration to neighbouring islands or to the closest continental territories ${ }^{(9)}$ Before the Second World War, migration to metropolitan France was limited to the elite. From 1945, the government - in particular the French Planning Commission (Commissariat général du Plan) via the second (1954) and third (1958) plans - encouraged the development of these flows. Those troops demobilized after the Second World War who were originally from the DOMs were encouraged to remain in metropolitan France, and the introduction of compulsory military service in the DOMs (1960), which was generally conducted in metropolitan France, encouraged the recruitment of migrants by the army. Under the Planning Commission, the DOM Commission recommended the introduction of a range of schemes combining propaganda and recruitment in the DOMs, medical testing, collective departures and arrivals in metropolitan France, housing assistance, social and technical assistance, credits, training, and professional integration. ${ }^{(10)}$ All these schemes assumed that the overseas migrants would need to "adapt to metropolitan life", from an assimilationist perspective (Pattieu, 2016).

(8) Income supplements paid according to the number of children and the number of parents taking care of these children.

(9) For example, between 1905 and 1907, 3,000 workers left Guadeloupe to work on the construction of the Panama Canal.

(10) At each planning stage, working groups were divided into commissions on particular subject areas. 


\section{The evolution of migration policies}

The creation of the Office for DOM Migration (Bumidom) was announced in 1962 with the aim of attracting between 6,000 and 7,000 migrants to metropolitan France per year. It began operating in 1963 and was dissolved in 1981. Between these two dates, the organization supported the migration of 160,300 Antilleans and Réunionese to metropolitan France, 17,200 of which were conscripts (Table 1 for Antilleans). It processed several Guianese files but was not directly active in Guiana. Its role in migration varied from providing small loans to facilitate access to accommodation, to full support, from departure to job placement (Pattieu, 2016). The Bumidom worked with the Ministry of Labour (Ministère du Travail), primarily through the Association for the Occupational Training of Adults (Association pour la formation professionnelle des adultes, AFPA), who focused mainly on men. The organization also worked with the Ministry for Population, Health and Social Services (Ministère de la Population, de la Santé et des Services sociaux), which generally offered training to women. With a view to ensuring permanent settlement, the Bumidom quickly promoted family migration along with labour migration.

Table 1. Antillean migrants supported by the Bumidom between 1963 and 1981

\begin{tabular}{|l|c|c|c|}
\hline & Men & Women & All \\
\hline Direct training placement & 9,202 & 2,003 & 11,205 \\
Direct employment placement & 14,645 & 15,791 & 30,436 \\
Placement after demobilization & 11,928 & 23 & 11,951 \\
Family reunification & 14,303 & 17,968 & 32,271 \\
\hline Total & 50,078 & 35,785 & 85,863 \\
\hline Source: Bumidom activity report (1981), Condon and Ogden (1991a). & \\
\hline
\end{tabular}

Training was often inadequate or poorly adapted to the skills of the migrants (Condon and Ogden, 1991b). It was also more focused on cultural integration and placement in precarious jobs than on enabling a professional career: "For many years, the 'training centres' operated by the Bumidom ... only provided classes on 'adapting to metropolitan life' and the level of professional preparation was low (domestic staff, warehouse staff, service representatives, etc.)" (Constant, 1987, p. 16). AFPA served more as a negative marker than as a springboard to permanent jobs. The workers who underwent this training were perceived as "the bottom of the pile" (Condon and Ogden, 1991a, p. 451) and sent to jobs rejected by métropolitains. The direction of migrants to certain occupations was focused on employers, for whom they constituted a poorly educated and flexible workforce, rather than on the employees who were placed in often precarious situations. This arrangement, advantageous to the employers, rendered organized migration a new "slave trade" (Anselin, 1990, p. 281). 
In fact, although demographic concerns lay at the heart of the introduction of the Bumidom, its creation was as much related to the strategy for economic growth in metropolitan France as to the overseas population control policy. ${ }^{(11)}$ Its facilitation of migration and its recruitment methods constituted a response to the labour shortage in public services in metropolitan France (in hospitals, for example), in state industry, and in the developing private sector (Condon and Ogden, 1991a, 1991b). Despite the fact that the overseas population continued to increase significantly in the 1980s, a less favourable metropolitan labour market slowed down mass movements of people. In 1982, the Bumidom was replaced by the National Agency for the Integration and Protection of Overseas Workers (Agence nationale pour l'insertion et la protection des travailleurs d'outre-mer, ANT). The focus of public policy turned to those who had left the DOMs and were already living in metropolitan France. This aboutturn also came in response to the claims of overseas campaigners who criticized the forced uprooting of the population, accusing the public authorities of overlooking more pressing concerns in the DOMs: improving levels of education and developing a more favourable labour market (Marie and Giraud, 1987).

From the 1980s, a two-pronged development transformed migration flows. First, public funding and organization of migration was reduced and, at the same time, working and housing conditions for migrants in metropolitan France deteriorated. It therefore became more difficult to move there. Secondly, new policies facilitated the emigration of overseas citizens with specific career paths. The extension of territorial continuity to the DOMs (2003), the Law on the Economic Development of Overseas Territories (2009) (Loi pour le développement économique des outre-mer), and the replacement of the ANT by the Overseas Agency for Mobility (Agence de l'outre-mer pour la mobilité, LADOM) in 2010 were particularly advantageous to young DOM inhabitants whose training or career paths were already well marked out. The selection of emigrants increased, but traffic between the DOMs and metropolitan France accelerated, supported by targeted mobility support (Temporal et al., 2011). While permanent migration to metropolitan France became rarer, the number of departures increased (Marie and Rallu, 2004). The trend among overseas citizens seemed, therefore, to have shifted from emigration to mobility, with shorter and shorter stays in the metropole. As migration was temporary, they may have been absent and not recorded by the censuses.

By looking back at the history of the Bumidom and the institutional devices that followed it, we can formulate hypotheses regarding the changes in these migration flows. According to these hypotheses, the Antilles and Réunion experienced mass migration between the 1960s and the 1980s which Guiana did not, and which fell sharply from 1981 onwards. During the 1980s and

(11) Issues relating to fertility and population grow th had become more urgent following increasing political unrest in the DOMs: Guadeloupe was rocked by riots in 1967, and there was violent conflict among the Martiniquan workforce during this period (Constant, 1987). 
1990s, more moderate levels of migration developed, involving more social selection. Although these major trends are supported by various data recording overseas mobility, the measures used do not always take into account the different dimensions of migration mechanisms. We need to construct an appropriate empirical tool for accurately measuring the role played by the Bumidom in the growth of migration flows, followed by the increase in selective metropolitan immigration and residency.

\section{Understanding migration mechanisms using censuses}

\section{Various data sources are available}

In recent decades, the study of migration has developed longitudinal approaches in response to a statistical problem: selection bias. Migrations and the duration thereof are not distributed randomly between individuals, which can distort the interpretation of certain statistics. For example, although the employment rate among immigrants may be higher than among those who remained in their country of origin, the labour market is not necessarily more favourable to them in the host society. It may be that those who left were the most qualified and/or those who did not find employment returned to their country of origin. Several empirical tools can be used to address these issues. In France, the Permanent Population Sample (Échantillon démographique permanent, EDP), an add-on to censuses since 1968, follows around $1 \%$ of the French population between one census and the next; it can be used to identify the mobility of immigrants and non-immigrants, as well as its effect on the integration of these populations (Caron, 2018; Solignac, 2016). In the absence of longitudinal data, individual data collected in host societies may also be combined with aggregate data collected in the country of departure, for example to situate immigrants within the distribution of educational levels in their country of origin (Feliciano, 2005; Ichou, 2014). As such, several large surveys have been used to collect information on migration from the DOMs to metropolitan France. On the other hand, they rarely meet all the criteria required for a robust study on the circumstances of emigration and immigration over time. The Trajectories and Origins survey (TeO, INSEE-INED, 2008) provides details of the movements of DOM citizens living in metropolitan France, but the numbers involved are too small to allow comparison of the various waves of migration. The Migration, Family, and Ageing survey (Migration, famille, vieillissement, MFV, INED, 2012) was conducted in the DOMs: it provides information on migrants who have returned, but their characteristics may be very different from those of individuals who remain in metropolitan France. ${ }^{(12)}$ Some years, INSEE's Labour Force Surveys

(12) It also enables us to compare the movements of the children of the survey respondents, living in metropolitan France or in the DOMS, but does not provide detailed information about their past mobility. 
also enable comparison between the DOMs and metropolitan France, but they do not show the migration date of individuals.

\section{Censuses and migration study}

While population censuses do not (apart from the EDP) provide individual longitudinal data, they do enable comparison of different waves of migration using the place-of-last-residence variable. Surveys have been conducted at regular intervals, both in metropolitan France and in the DOMs. The exhaustive nature of the censuses up to 1999 means that there is no issue with numbers involved. Since 2004, the censuses have been conducted via an annual survey and can provide a full sample every five years. Using the 2007 census, Temporal and Marie (2011) demonstrated that migration away from the DOMs is more common among the more highly educated individuals. Likewise, the level of education among overseas migrants is higher than among those living in the DOMs. The distribution of degrees among overseas migrants is close to the metropolitan average, which was not the case for preceding generations. They are also more likely to have access to stable employment. The limitation of these measurements is that we cannot separate pre-migration and post-migration characteristics. We cannot, therefore, differentiate between what is a result of selection and what is a result of the opportunities on offer in metropolitan France. Their article reminds us that the better working conditions of overseas citizens living in metropolitan France is primarily due to their better qualifications, often acquired there. ${ }^{(13)}$ In addition, knowing that a degree was acquired after migration does not mean it is unrelated to migration selectivity if only those more capable of pursuing higher education decide to leave the DOMs. This article tries, therefore, to explore the use of censuses more deeply. Analysis of censuses over the long term and association with complementary statistical approaches provide a better understanding of the selection phenomenon in the context of migration.

\section{The censuses used}

The population census tools reveal the ambiguity of departmentalization, encompassing both continuity with metropolitan France and continued specificity of the overseas territories. Since 1954, the DOMs have been included in the census using a methodology similar to that used in metropolitan France. ${ }^{(14)}$ At the same time, they are still treated separately. In 1961, 1967, and 1974, the census took place one year before the census conducted in metropolitan France.

(13) $\mathrm{TeO}$ estimates that nine out of ten DOM university graduates living in metropolitan France obtained their degree in metropolitan France.

(14) “DOMization' was accompanied by the use of the same census and civil status forms in the DOMs as in metropolitan France, except for a few minor differences. [...] However, the 1954 and 1961 censuses in Guiana still identified a 'primitive' population divided into 'Indians' and 'blacks.'” (Rallu, 1998, p. 601). 
Even today, census results distinguish the metropolitan area from DOM-specific censuses, and they are published separately and archived using different methods. In the coding of the variable for place of birth, the metropolitan census of 1962 makes no distinction between Martiniquans and Guadeloupeans (natives of the Antilles), nor between Guianese, Réunionese, and natives of overseas territories.

This article looks at the censuses conducted in metropolitan France and in the DOMs between 1954 and 1999. The results from 1954 to 1962 are only used at an aggregate level to measure the number of DOM inhabitants and the number of people born in the DOMs living in metropolitan France. The detailed census files used in metropolitan France since 1968 provide individual data, enabling us to study the profiles of overseas migrants. However, those for the DOM censuses are only available from 1974. An analysis combining DOM and metropolitan data is therefore only possible from this date onwards. It should also be conducted with caution. First, the census corresponding to the metropolitan 1975 census took place in 1974 in the DOMs. Secondly, even though the 1982 census took place at the same time in the DOMs and metropolitan France, the collection methods used and the questions asked were only completely standardized from 1990 onwards.

\section{A cohort of migrants approach}

The analysis is broken down by age, department of birth, and sex. The "department of birth" and "department of residence at the last census" variables identify people born in the DOMs who moved to metropolitan France between two censuses, enabling us to define cohorts of migrants. The previous residence variable arises from a retrospective question, which asks individuals to think back to a specific time in the past: this limits the quality of the information obtained. ${ }^{(15)}$ Studies particularly show that the non-response rate to this question, as well as the inconsistencies with other information on trajectories, are particularly high for immigrants (Solignac, 2016). Nevertheless, this variable remains one of the principal resources for estimating migration flows (Brutel, 2014). People living in metropolitan France who were born in a DOM and indicated their DOM of birth as their place of residence at the last census are considered overseas migrants who arrived between two censuses. As censuses were conducted between seven and nine years apart, the flows recorded using this measurement are primarily those who remained on a long-term basis, as shorter stays were rarely recorded. ${ }^{(16)}$ The shorter the interval between censuses, the greater the number of entries made. This is why the detailed use of censuses stops in 1999: the movement

(15) Census respondents were asked to state their place of residence as of 1 January of the year of the previous census.

(16) Return trips that took place between two censuses were even overlooked, since these individuals were not included in a metropolitan census. 
from a comprehensive data collection to annual surveys changes the nature of the migrations recorded.

As the Bumidom was active from 1963 to 1981, the census dates correspond almost perfectly to those of the Bumidom's activity. The effects of the Bumidom are analysed by comparing the migration flows during its period of activity (using the 1968, 1975, and 1982 censuses) with those of the following period, and by comparing the DOMs affected (the Antilles and Réunion) with one unaffected (Guiana). By checking the Bumidom's activity reports (1981) against the census data, we estimate that around $40 \%$ of those who migrated between 1963 and 1981 used its services. The census does not distinguish migrants supported by the Bumidom from those who were not. As such, this assessment of a "Bumidom effect" does not look directly at the impact of this organization on the individual trajectories of the people whose journeys it supported. However, it does look at how the organization's activity in certain DOMs affected the volume and composition of migration from these departments to metropolitan France as a whole.

\section{A reconfiguration of overseas migration}

\section{The various dimensions of changes in flows}

There is no doubt about the mass nature of the migration supervised by the Bumidom (Table 1). Nonetheless, it is difficult to know if this organization recorded migrations that would have taken place regardless, or if it truly generated new departures. As such, to understand the effect of the Bumidom on DOM-metropolitan France flows, we need to compare the changes in these flows in the Antilles, Réunion, and Guiana. The trends evidenced by various types of demographic measurements highlight the multidimensional nature of migration phenomena. Levels of overseas migration can be measured by numbers of people, as a percentage of the native DOM population, or by rate of growth. The contrast between these indicators provides a more in-depth understanding of DOM-metropolitan France migration.

\section{Slow-down of flows but stability of emigration rate}

The number of people who were born in the DOMs and moved to metropolitan France between two censuses almost tripled between 1968 and 1982, and then fell between 1990 and 1999, although not as low as its 1968 level (Figure 2). Breaking these flows down by DOM of birth seems to confirm the uniqueness of Guiana and the intensity of the Bumidom effect. The flows of immigrants from Guiana are, from 1968 onwards, much smaller than those from the other DOMs and show a moderate but consistent increase from 1968 to 1999. Between 1968 and 1982, ten times more immigrants arrived from the Antilles and Réunion than from Guiana. Numbers increase more 
significantly between these dates, then decline from 1982 onwards. The low numbers of Guianese migrants is primarily explained by the smaller size of the population (in 1961, there were ten times fewer residents of Guiana than of Réunion). In terms of rate of variation, these flows tripled between 1968 and 1982, following the overall trend. The effect of the Bumidom, which was not active in Guiana, is perhaps more visible after it closed than during its operation: whereas, from 1982 onwards, the three DOMs in which the Bumidom operated saw a significant fall in the number of people leaving for metropolitan France, this was not the case in Guiana. As such, it was the actions of the Bumidom that enabled flows from Réunion and the Antilles to experience the same growth as the Guianese flows.

Figure 2. Population born in the DOMs who moved to metropolitan France between the 1968 and 1999 censuses

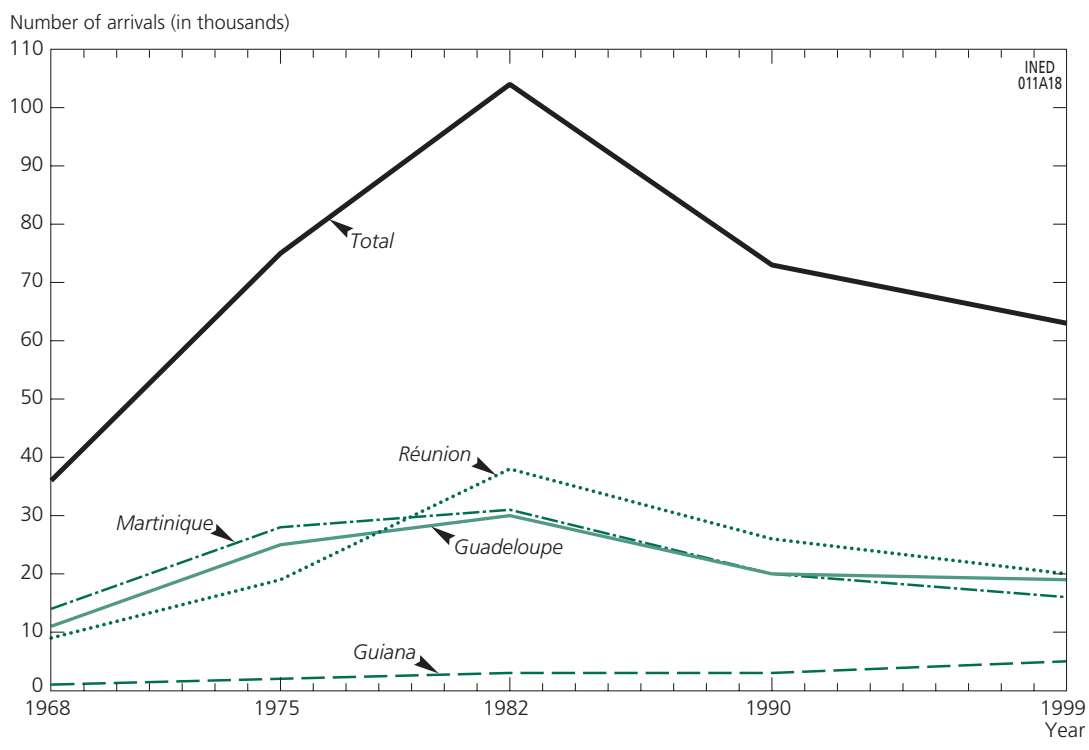

Source: Population censuses (INSEE).

If we look at the number of DOM natives living in metropolitan France rather than at the number of people who arrived between two censuses, we can go back as far as 1954. Using this information and the number of DOM natives still living in their DOM of birth ${ }^{(17)}$ we can calculate the proportion of DOM natives living in metropolitan France (Figure 3). ${ }^{(18)}$ As the 1962 census does not provide detailed origins, the figures for this year are calculated using

(17) This information is only available from 1975 onwards, but as flows into the DOMs between 1954 and 1975 were so small, we can use the total population as an approximation (Rallu and Diagne, 2005).

(18) This proportion therefore omits DOM natives living abroad. However, the Migration, Family and Ageing (MFV) survey can be used to estimate that expatriates represented 1\% of DOM natives in 2012; this percentage was probably even lower during the time periods we are looking at. 
approximations. ${ }^{(19)}$ In 1954 , Guiana was affected more by emigration to metropolitan France than the other DOMs. From 1968 onwards, the proportion of metropolitan residents grew slightly less than those of the other DOMs and then fell from 1982 onwards. The percentages of Martiniquan and Guadeloupean emigrants are very similar and evolve in parallel throughout the period. They increase until 1982, with particularly strong growth between 1968 and 1982, then stabilize. The Réunionese record the lowest proportion of metropolitan residents, on average twice as low as those of the Antilles, but the trend is similar.

Figure 3. Percentage of the population born in the DOMs and living in metropolitan France between the 1954 and 1999 censuses

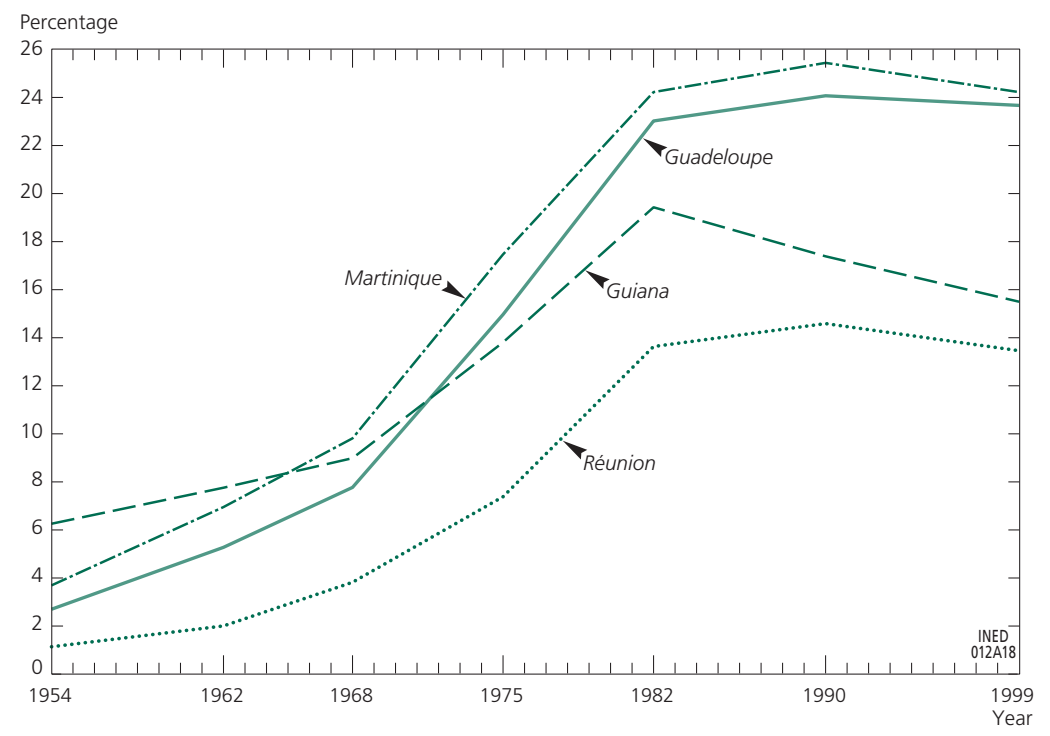

Source: Population censuses (INSEE).

Between 1982 and 1999, we therefore see different trends in terms of the size of flows and the proportions of natives living in metropolitan France. On the one hand, the closure of the Bumidom was accompanied by a reduction in flows that is not seen for Guiana. On the other hand, the closure of the Bumidom was accompanied by the stabilization of the proportion of emigrants to metropolitan France for the Antilles and Réunion, whereas for Guiana, this proportion fell. The proportion of DOM natives living in metropolitan France

(19) These approximations are obtained from aggregate figures for the Antilles, on the one hand, and for Réunion, Guiana, and the TOMs (territoires d'outre-mer), on the other. We use the relative percentage of each DOM in these aggregate figures for 1954 and 1968, calculating the average to produce the relevant percentage in 1961, which is then applied to the aggregate figures for 1961. For example: Guianese in metropolitan France in 1961 = (Guianese, Réunionese, and TOM citizens in metropolitan France in 1961) × [(percentage of Guianese from the Guianese, Réunionese, and TOM citizens in metropolitan France in 1954) + (percentage of Guianese from the Guianese, Réunionese, and TOM citizens in metropolitan France in 1968)] / 2 
not only expresses the propensity to migrate, it also reflects the number of years spent in metropolitan France, which is subject to returns to DOM of origin and length of life. By comparing the size of the flows and the proportion of emigration within the native population of the DOMs, we can assess the various dimensions of the change in migration over time. Although there were fewer migrations from the Antilles and Réunion after the closure of the Bumidom, the organization nonetheless promoted sustainable residencies, with the result that the Antillean and Réunionese diasporas remained in place through the years. On the other hand, Guianese migrations became more numerous but of shorter duration, and increased less quickly than the population of natives: the percentage of emigrants among the Guianese population continued to fall.

\section{Differences in the temporality of migrations}

To better determine the role of the various migrations at different ages, we calculate the net migration focused on DOM natives: for each census year, for each age, sex, and DOM, the number of people born in the department who have moved to metropolitan France since the previous census is subtracted from the number of people born in the department and returning there (Figure 4). ${ }^{(20)}$ For each group, the number of departures corresponds to the number of individuals listed in the metropolitan census and indicating their DOM of birth as their department of residence at the time of the previous census; the number of returns corresponds to the number of individuals recorded in the census of their DOM of birth and indicating a metropolitan department as their department of residence at the previous census:

Net migration $=$ Returns from metropolitan France $\rightarrow$ DOM - Departures

from DOM $\rightarrow$ metropolitan France

Departures are mostly undertaken between 18 and 30 years of age. In 1975, the migratory balance of females was higher than males (with the exception of Martiniquan females). The curves converge from 1982 onwards and progress similarly. Male migration had increased prior to the creation of the Bumidom (particularly with conscription). Initially, female migrations were chiefly those of the wives and companions of men recruited by the administrative authorities (Condon, 2008). They were quickly joined by single women recruited for positions such as domestic and care-home workers, which explains this convergence. In Guiana, net migration becomes positive again after the age of 28 , and we see few differences between the various censuses. For the other DOMs, net migration becomes positive again only after the age of 31 , in fact only after age 46 in some cases. The change in net migration for the Antilles and Réunion also features the emergence of a peak of returns between 31 and 45 years of age. From 1990 onwards, the net migration for Guadeloupeans between 31 and 45 years of age exceeded 100 per age, i.e. approximately 1,500

(20) For the age categories (31-45 years, 46-60 years, 60 years and over), the net figure is divided by the number of years in the category. 
Figure 4. Population born in the DOMs - balance of departures to metropolitan France and returns to the DOMs by age and sex between the 1975 and 1999 censuses
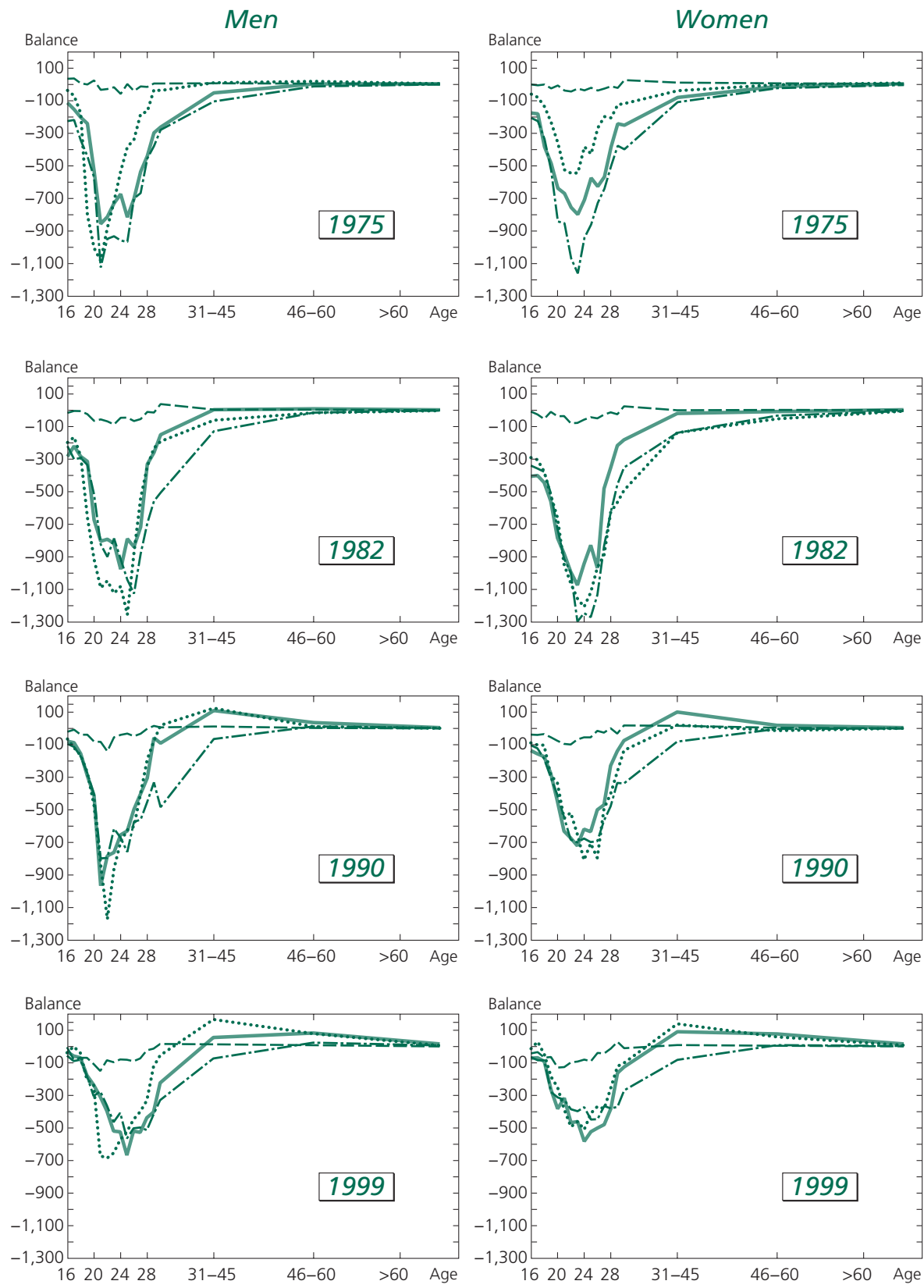

\begin{tabular}{|c|c|c|c|c|}
\hline — Guadeloupe & -- Guiana & -.- Martinique & ...... Réunion & $\begin{array}{l}\text { INED } \\
\text { O13A18 }\end{array}$ \\
\hline
\end{tabular}

Source: Population censuses (INSEE). 
for the age group. Réunion saw the same transformation in 1999. For Martiniquans, the balance of 31-45 year olds remained negative until 1999, but still grew over the long term.

Although the Bumidom had a strong impact on migrations from the Antilles and Réunion, it was not the only factor to increase flows. It appears that, without its intervention, departures from these three DOMs to metropolitan France would still have increased significantly between 1960 and 1980. On the other hand, the Bumidom's work intensified this increase and created more long-term settlement. The emergence of a peak of returns from 1990 onwards (as was noticeable for Guianese flows since 1975) suggests that the less favourable economic context prompted a significant proportion of migrants to return to their DOM of origin after the age of 30, whereas the organization promoted permanent migration to metropolitan France.

To better determine the influence of the Bumidom on the increase in flows, as well as the influence of other factors on migration, we estimate regressions using difference-in-differences. We start by explaining the methodology of this estimation technique, borrowed from the assessment of public policies, and then justify the construction of the explanatory variables, before presenting the principal results.

\section{Description of the method}

Difference-in-differences, or the double difference method (see Box), can be used to evaluate the effect of a "treatment" (such as a public policy tool). It is based on the comparison of observations within treatment and control groups, as well as during periods of treatment and non-treatment. It is this double comparison that gives its name to the method and robustness to the estimation, without requiring panel data. In this case, we are estimating the impact of the Bumidom on the rate of intercensus variation in flows from the DOMs to metropolitan France. This approach allows us to eliminate the effect of the metropolitan context on migration because this would have affected Guiana and the other DOMs in the same way. The treatment period is that during which the Bumidom was active: the flows recorded between 1968 and 1975 (1975 census), and between 1975 and 1982 (1982 census). The treated groups are Martinique, Guadeloupe, and Réunion.

To construct the explanatory variable, we start with the number of immigrations between each census. To take differing census intervals into account, this number is divided by the number of years between each census, producing an average number of arrivals per year for the period. Due to its smaller population, the flows from Guiana are numerically far lower than the others. To make any meaningful comparison between the four DOMs, we therefore need to use rates of variation rather than absolute variation. To this end, the variable explained by the regression is the logarithm of the average annual number of migrations to metropolitan France between two censuses. 


\section{The double difference method}

The double difference method was developed in response to an increasing need to assess public policies (Givord, 2014). It is based on Rubin's analytical framework (Rosenbaum and Rubin, 1983), which supposes the construction of a hypothetical counterfactual (the situation that would have been observed in the absence of the programme). Where $T$ is a treatment, $Y^{0}$ the outcome associated with $T=0$ (no treatment) and $Y^{1}$ the outcome associated with $T=1$ (treatment). The effect of the measure on the individual $i$ is represented as: $\Delta_{i}=Y^{1}{ }_{i}-Y^{0}{ }_{i}$

We never observe both $Y^{1}$ and $Y_{i}^{0}$ at the same time. A so-called "naive" estimator simply compares the average outcome observed in the treated groups and control groups. However, this estimator is a priori biased: those treated are not randomly selected, and the outcome without treatment is not independent of the fact of following the treatment. Comparing the treated groups before and after the reform is not appropriate either (as many other time-related factors may explain the variation observed). Difference-indifferences estimators combine these two approaches. By comparing both periods and groups, we control both the temporal trend and the differences between groups.

The specific effect: $\Delta=E\left(Y_{i t}{ }^{1}-Y_{i t}{ }^{0} \mid T=1\right)-E\left(Y_{i t}{ }^{1}-Y_{i t}{ }^{0} \mid T=0\right)$ is estimated using the equation: $Y_{i t}=\alpha+\beta 1_{(\mathrm{t}=1)}+{ }_{\gamma} 1_{(\mathrm{i} \in \mathrm{GT})}+\delta T_{i t}+u_{i t}$

Where $T_{i t}$ is the indicator that takes value 1 when the individual $i$ benefits from the measure at date $t$

\section{Such that $\hat{\Delta}=\hat{\delta}$}

This is an unbiased estimator of the specific effect of the treatment if we hypothesize that the groups would have evolved in the same way in the absence of treatment (parallel trend assumption). We therefore have to select a plausible control group. The argument is that, in the case of the Bumidom, the non-treatment of Guiana constitutes a "natural experiment" which provides the control group. In addition, having more information about the groups concerned, as is the case here, allows for more flexibility in the parallel trend assumption.

The results read as follows: an increase of 1 unit in variable $\mathrm{x}$ is related to an increase of [coefficient] \% in flows. The explained variable is therefore the rate of variation of flows by DOM, by sex, and by age. Migrations were mainly undertaken between the ages of 18 and 30. Thus, the age categories used were as follows: under 16 years of age, each age between 16-30, 31-45, 46-60, and over 60 years of age. ${ }^{(21)}$ The explanatory variables include contextual information on the DOMs at the previous census, whereas the censuses in the DOMs are only available from 1974 onwards. ${ }^{(22)}$ The analysis is therefore reduced to the

(21) Using an observation for every age would give too much weight to flows that do not reflect the reality of migrations as a whole, and there would be disproportionate variance in their rate of variation.

(22) Taking these contexts into account enables us to better ensure that the parallel trend assumption holds true, i.e. the fact that the flows compared would have evolved similarly without treatment (Givord, 2014). 
1982, 1990, and 1999 censuses. ${ }^{(23)}$ With 19 age categories for each sex, in four departments and for three dates, the database contains 456 observations.

\section{Explanatory variables}

For each cohort, we considered, as explanatory variables for migration, the situation in the DOM for the preceding cohort: the labour market participation rate, the unemployment rate, the proportion of those in higher-level occupations (cadres) and the proportion of holders of an upper-secondary qualification (bacheliers). For example, the increase between 1975 and 1982 in the flows of 21-year-old Guadeloupeans is explained by the proportion of 21-year-old Guadeloupeans who held an upper-secondary or higher qualification in Guadeloupe in 1974. It involves capturing the prospects that the members of a cohort believe they have for the future, based on the characteristics of the cohorts during the previous period. Given the specific position within the life cycle of the under 16 and over 60 categories, making it less appropriate to use expectations in terms of qualifications and employment, the contextual information for the whole population of that sex is attributed to them. The definition of unemployment in the census does not match that of the International Labour Organization, which is usually used as the basis for measuring unemployment rates. It has a broader interpretation of the concept of looking for work, which produces higher figures. In the DOMs, the labour market is not organized in the same way as in metropolitan France, and the spectrum of "actually seeking employment" is much more difficult to determine (Domenach and Guengant, 1981). The way in which individuals register as unemployed also varies over time, particularly with changes in the benefits system. Difficult to interpret in absolute terms, the measurement of unemployment according to the census definition makes sense when comparing one DOM against another and over time. The distribution of these variables over time is reported in Appendix Tables A.1, A.2, and A.3.

The majority of migration theories are based on the structure of the labour markets in the societies of origin and/or host societies being the causal mechanism of migration. For example, while neoclassical economists highlight differences in employment rates and wages, the dual labour market theory emphasizes the role of labour demand and the strategies of recruiters (Massey et al., 1993; Piore, 1979). These paradigms are concurrent but not necessarily contradictory. The context in which DOM-metropolitan France migration developed seems to confirm them: the high unemployment rates in the DOMs, as well as the shortage of labour in metropolitan France and the Bumidom's recruitment campaign can explain the increase in flows until the 1980s. However, since the post-war period, labour migration has taken place in parallel with another type of mobility: the young descendants of the overseas elite have been coming to metropolitan France to study. Since the 1960s, mass education

(23) Analyses with the four periods, but without the contextual variables, have been conducted and confirm the results. 
policies have brought more and more pupils up to upper-secondary level. Despite the fact that levels of education remain far lower in the DOMs, an increasing number of young DOM citizens are in a position to pursue university studies. If the tertiary education on offer in their department is not adequate, these young people will also be prompted to migrate. The endogenous nature of the number of educational establishments and places available makes it difficult to include them in the model. Nonetheless, we should note that as of 1975 there were no universities in the DOMs and, as of 1982, none in Guiana, which certainly influenced these departures.

\section{Results of the difference-in-differences models}

Table 2 contains the results of the four double-difference regression models. One explanatory variable is added at each step. The basic model estimated the effect of the Bumidom at $78 \%$ in terms of increase in flows. Taking into account the context of the region of origin for each cohort at the previous census modifies this first estimate, although the effect remains high. In the final model (column 4), the effect of the Bumidom is estimated at $72 \%$. The proportion of those with an upper-secondary qualification has a positive effect on migration. The positive effect of the proportion of those in higher-level occupations disappears and becomes negative once employment and unemployment rates are taken into consideration (an increase of one percentage point reduces the flows by $7 \%$ ). This effect suggests that increasing opportunities in terms of social mobility act as a brake on migration. In contrast to the hypotheses of the neoclassical paradigm, the unemployment rate has a weak but negative

Table 2. Results of the difference-in-differences regressions on the rate of variation of flows

\begin{tabular}{|c|c|c|c|c|}
\hline & 1 & 2 & 3 & 4 \\
\hline Treatment period & -0.06 & 0.18 & 0.17 & -0.19 \\
\hline Treatment group & $1.71 * * *$ & $1.73 * * *$ & $1.75^{\star \star \star}$ & $1.91 * \star \star$ \\
\hline Difference-in-difference & $0.78 * * *$ & $0.77 * * *$ & $0.76 * * *$ & $0.72 * * *$ \\
\hline $\begin{array}{l}\text { Proportion with upper- } \\
\text { secondary qualification }\end{array}$ & & $0.03 * * *$ & $0.02 * * *$ & 0.01 * \\
\hline $\begin{array}{l}\text { Proportion working in } \\
\text { a higher-level occupation }\end{array}$ & & & $0.05^{* *}$ & $-0.07 * *$ \\
\hline $\begin{array}{l}\text { Labour market } \\
\text { participation rate }\end{array}$ & & & & $0.00 *$ \\
\hline Unemployment rate & & & & $-0.02 * * *$ \\
\hline Constant & $2.19 * * *$ & $1.77 * * *$ & $1.67 * * *$ & $2.48 * * *$ \\
\hline N & 456 & 456 & 456 & 456 \\
\hline Adjusted $\mathrm{R}^{2}$ & 0.562 & 0.594 & 0.602 & 0.642 \\
\hline \multicolumn{5}{|c|}{$\begin{array}{l}\text { Interpretation: According to Model } 2 \text {, an increase of one percentage point in the proportion of those with a } \\
\text { upper-secondary qualification in a cohort increases the number of migrants produced from this cohort by } 3 \% \\
\text { Significance levels: }{ }^{*} p<0.05 ;{ }^{*} p<0.01 ; * * * p<0.001 \\
\text { Source: Author's estimates from INSEE population censuses. }\end{array}$} \\
\hline
\end{tabular}


effect on flows (an increase of one percentage point reduces flows by $1-2 \%$ ). This effect may be related to the cost of migration: populations living in precarious situations do not have the resources to move to metropolitan France.

The use of difference-in-differences methods confirms the strong impact of the Bumidom on the growth of DOM-metropolitan France flows. These regressions also highlight the role of other structural factors. They qualify the importance of unemployment: while individuals are likely to migrate to find a job in metropolitan France, a high unemployment rate also reflects precarious socioeconomic conditions. And yet, migrating is expensive: mobility requires both financial resources and information, while also involving a certain level of risk. Even assuming that the metropolitan labour market is more favourable to them, the most disadvantaged populations do not necessarily migrate because they have to bear these costs before gaining the potential benefits of migration. Nonetheless, the negative effect of the proportion of those in higher-level occupations supports the idea that the development of economic and professional opportunities in the societies of origin tends to reduce migrations to metropolitan France.

\section{Different and selected migrants?}

Migration for education and migration for labour do not constitute two separate models of mobility. While a metropolitan education constitutes a very profitable resource on the overseas labour market, qualified migrants return less often to their DOM of origin than others do (Temporal et al., 2011). A mobility plan involving a metropolitan education is often combined with a plan to pursue a career in metropolitan France. Alternatively, the latter may be imposed, such as for police officers who are trained in metropolitan France (with the exception of rare overseas exams) and then find it difficult to obtain a transfer back to the DOMs. But this is not necessarily the case. Because their qualifications give them better access to jobs, when overseas migrants who came to metropolitan France for educational purposes remain there, a gap opens up between DOM natives who leave and those who stay. In order to understand how this gap emerges, we have to use measurements that determine the various types of selection at work in the process.

The higher levels of education among DOM natives living in metropolitan France can be explained by two phenomena. First, if migration is selective (i.e. accessible only to a fraction of the population in terms of aspirations and costs), migrants leave with more expectations in terms of higher education. Secondly, if the higher education and training on offer in the DOMs is limited, leaving enables migrants to achieve higher levels of education. The discrepancy in the distribution of educational level between the territories thus reflects not only migration selectivity but also the effect or the driver of this migration. The higher level of educational attainment among migrants may be seen either as a form of social mobility offered to the latter or as proof of their social selection. To distinguish these two dimensions, the analysis focuses on educational levels 
acquired prior to migration but which remain discriminative, and on the fact of continuing education past upper-secondary level.

Attaining the upper-secondary level appears to be a key point in the careers of overseas citizens exposed to mobility. Although some migrants are minors (who are following or joining a parent), migration mainly takes place between the ages of 18 and 30: in most cases, an individual on a pathway involving an upper-secondary qualification will have already obtained it prior to his or her arrival in metropolitan France. In addition, secondary education is not subject to the same limitations of availability as higher education, and there is continuity between the secondary schools in metropolitan France and those of the DOMs. Lastly, having an upper-secondary qualification is a necessary prerequisite of access to higher education. Initially, therefore, we compare the proportion of individuals with at least the upper-secondary qualification among DOM natives who arrived between two censuses, with the proportion of those having an upper-secondary qualification among those who remained in their DOM of birth. To avoid the result being sensitive to a generational effect (as those under 30 are over-represented in the new arrivals, these flows are more exposed to an overall increase in educational level than DOM natives as a whole), the populations studied are reduced to a ten-year cohort, the 18-27 year olds. ${ }^{(24)}$ This comparison is expressed in the form of odds ratios. The same comparison is applied to the fact of having a lower-secondary vocational qualification (certificat d'aptitude professionnelle, CAP) or higher. Lastly, of the DOM natives aged 18-27 with at least an upper-secondary qualification, the odds ratios compare the proportion of individuals who are still students in the two groups. These results are presented in Table 3. The detailed results per DOM are provided in Appendix Table A.4.

Table 3. Odds ratios comparing the education of overseas citizens who moved to metropolitan France between two censuses against that of overseas citizens living in their DOM of origin

\begin{tabular}{l|c|c|c|}
\hline & $\begin{array}{c}\text { With at least a CAP } \\
\text { (aged 18-27) }\end{array}$ & $\begin{array}{c}\text { With at least } \\
\text { an upper-secondary } \\
\text { qualification (aged 18-27) }\end{array}$ & $\begin{array}{c}\text { Continuing education for those } \\
\text { with an upper-secondary } \\
\text { qualification, aged 18-27 }\end{array}$ \\
\hline 1975 & 3.7 & 2.7 & 3.7 \\
1982 & 4.6 & 2.7 & 3.0 \\
1990 & 3.1 & 3.1 & 1.7 \\
1999 & 3.4 & 2.8 & 2.2 \\
\hline Interpretation: In 1999, a DOM citizen aged 18-27 who moved to metropolitan France between 1990 and \\
1999 was 2.8 times more likely to have at least an upper-secondary qualification than a DOM citizen aged 18-27 \\
who remained in their DOM of birth. \\
Source: Population censuses.
\end{tabular}

(24) The over-representation of certain ages among the migrants constitutes itself a form of selection that explains the discrepancies between the overseas citizens who moved to metropolitan France and those who remained in their DOM of birth. 
The first finding is the high selectivity in terms of educational level, regardless of the point in time or the DOM. DOM citizens aged 18 to 27 who migrated between two censuses are almost three times more likely than those who remained in their DOM of birth to have an upper-secondary qualification or higher. On the other hand, no clear increase in selectivity is observed over time. Levels of upper-secondary attainment remain stable between 1975 and 1982, increase in 1990, and then return to the previous level in 1999. Overall, selectivity on the basis of qualification in 1999 is at a similar level to that of 1982. Levels of CAP attainment increase between 1975 and 1982, fall in 1990, and increase again in 1999. Furthermore, the results are not consistent between one DOM and another. In Guadeloupe and Martinique, selectivity on the basis of qualification is higher in 1999 than in 1982, regardless of the benchmark used. In Guiana and Réunion, on the other hand, it is lower.

In terms of continuing education after the upper-secondary level, the careers of migrants also differ dramatically from those of DOM citizens who remain in their DOM of birth. In 1975, those with an upper-secondary qualification aged 18 to 27 who arrived in metropolitan France between two censuses are nearly four times more likely still to be students than those who did not migrate. But the trend observed is a narrowing of this gap, presumably due to the higher education provision in the DOMs catching up with that of metropolitan France. The Sirene register shows that the number of higher education establishments in Guadeloupe increased from 9 in 1990 to 13 in 1999, from 5 to 9 in Martinique, from 1 to 2 in Guiana, and from 6 to 11 in Réunion. ${ }^{(25)}$ Continuing education nonetheless remains significant: in 1999, those with an upper-secondary qualification aged 18 to 27 who arrived in metropolitan France between two censuses are twice as likely still to be students than those who remained in the DOMs. Again, developments within the various DOMs are not consistent. Narrowing of the gap is seen in Guadeloupe and Réunion but not in Martinique or Guiana. The discrepancy in educational level between migrants and those who remained in the DOMs is therefore the product of a double mechanism: it clearly results both from high migration selectivity and better and more diverse higher education opportunities in metropolitan France (even though the calculations performed do not completely eliminate the effect of pre-migration dispositions). Where the discrepancy is heightened over time, this is not the result of any intensification of these mechanisms (the odds ratios did not increase, and even decreased to a certain extent).

(25) Where a university has several teaching and research units, each is counted separately, not the university as a whole. 


\section{Conclusion}

Migration from the DOMs to metropolitan France offers a unique empirical case for improving our understanding of the mechanisms of geographical mobility. The specificity of these territories and their populations, significantly shaped by their colonial past and by their history of access to French citizenship, provides a new perspective on migration within France since the post-war period. On the one hand, the DOMs are situated thousands of kilometres from metropolitan France and, as in many cases, migration is costly and the distances involved significant. On the other hand, DOM natives are French citizens and, since departmentalization in 1946, have been progressively integrated into institutional systems similar to those of metropolitan France. They face no legal barrier to migration, receive primary and secondary education based on the metropolitan system, and can access the same social infrastructures in metropolitan France as other French citizens. Nonetheless, between the 1960s and the 1990s, "DOM-specific adjustments" still existed in law and practice. These reflected the public authorities' concern about the growth of the overseas populations, which they tried to control using policies to curb fertility and encourage mobility. The Bumidom is characteristic of this intervention. By studying its impact, we can observe the effect of institutional measures on migration flows, by differentiating this effect from mechanisms associated with the socioeconomic conditions that existed in the DOMs and in metropolitan France.

Through careful analysis of the censuses conducted in metropolitan France and in the DOMs between 1968 and 1999, this study has produced three significant results. First, the Bumidom had a strong positive impact on the increase in migrations from the Antilles and Réunion, net of the effect of context in the DOMs. It increased the number of migrants and the duration of their residencies in metropolitan France. Secondly, the mass migration of the 1960s and 1970s was not only related to the Bumidom's work. The impact of socioeconomic conditions in the DOMs suggests that significant movement would have taken place even without its intervention. Looking beyond the paradigm of labour migration (which remains an important factor of mobility), the analysis reveals the importance of educational aspiration. Access to higher education has also been a driver of migration from the DOMs to metropolitan France since the 1960s. Lastly, the encouragement of mass migration came to an end, marked by the replacement of the Bumidom by the ANT, and the deterioration of metropolitan economic conditions transformed the structure of migration from the 1980s onwards. Although selectivity and disparity in relation to educational level did not increase, the gap between migrants and those who remained in their DOM of birth was accentuated by the overall increase in qualifications and the new constraints of the labour market, which was increasingly unfavourable to those with fewer qualifications. 
Most studies that theorize links between migration policies and the development of flows focus on whether or not states decide to restrict entry to their territory, and on their ability to enforce these restrictions (Zolberg, 1999). This article contributes to a better understanding of the role of public institutions in the development of migration by analysing a different type of migration policy: the use of organizations set up to support migrants favourable to migration. These results show the interaction between state policies, the socioeconomic context in the region of departure, and the socioeconomic context in the region of arrival.

Acknowledgements: This work was supported by a public grant overseen by the French National Research Agency (ANR) as part of the "Investissements d'avenir" programme, (reference: ANR-10-EQPX-17 - Centre d'accès sécurisé aux données - CASD). 
APPENDIX 

Table A.1. Employment, educational level, and emigration in the DOMs of 16-30-year-olds (\%) at censuses conducted between 1975 and 1999

\begin{tabular}{|c|c|c|c|c|c|c|}
\hline & Farmers & $\begin{array}{c}\text { Those in } \\
\text { higher-level } \\
\text { occupations }\end{array}$ & $\begin{array}{l}\text { Those with } \\
\text { an upper- } \\
\text { secondary } \\
\text { qualification }\end{array}$ & $\begin{array}{l}\text { Employed } \\
\text { workforce }\end{array}$ & Unemployed & $\begin{array}{c}\Delta \text { flows to } \\
\text { metropolitan } \\
\text { France }\end{array}$ \\
\hline \multicolumn{7}{|c|}{1975} \\
\hline Guadeloupe & 5.0 & 3.1 & 6.0 & 61.7 & 37.9 & 97 \\
\hline Martinique & 1.5 & 2.0 & 6.2 & 60.6 & 37.4 & 88 \\
\hline Guiana & 7.0 & 3.5 & 6.0 & 58.3 & 17.1 & 40 \\
\hline Réunion & 7.7 & 3.1 & 4.5 & 55.2 & 31.8 & 91 \\
\hline \multicolumn{7}{|c|}{1982} \\
\hline Guadeloupe & 4.5 & 3.7 & 8.0 & 56.8 & 43.6 & 30 \\
\hline Martinique & 1.3 & 3.5 & 8.2 & 58.4 & 50.0 & 13 \\
\hline Guiana & 11.4 & 3.9 & 8.8 & 61.3 & 23.6 & 68 \\
\hline Réunion & 5.9 & 3.4 & 7.7 & 54.5 & 47.2 & 87 \\
\hline \multicolumn{7}{|c|}{1990} \\
\hline Guadeloupe & 1.7 & 2.4 & 19.0 & 60.3 & 49.1 & -38 \\
\hline Martinique & 1.3 & 3.2 & 20.7 & 60.9 & 52.3 & -42 \\
\hline Guiana & 6.6 & 3.9 & 19.3 & 58.8 & 35.0 & -4 \\
\hline Réunion & 2.4 & 2.6 & 15.2 & 59.5 & 50.5 & -39 \\
\hline \multicolumn{7}{|c|}{1999} \\
\hline Guadeloupe & 1.2 & 2.4 & 25.9 & 55.1 & 51.9 & -27 \\
\hline Martinique & 0.9 & 3.2 & 27.2 & 52.8 & 50.8 & -38 \\
\hline Guiana & 4.0 & 5.2 & 17.6 & 49.0 & 42.6 & 18 \\
\hline Réunion & 1.4 & 3.0 & 22.9 & 56.4 & 55.4 & -33 \\
\hline
\end{tabular}


Table A.2. Employment, educational level, and emigration in the DOMs of 31-45-year-olds (\%) at censuses conducted between 1975 and 1999

\begin{tabular}{|c|c|c|c|c|c|c|}
\hline & Farmers & $\begin{array}{l}\text { Those in } \\
\text { higher-level } \\
\text { occupations }\end{array}$ & $\begin{array}{l}\text { Those with } \\
\text { an upper- } \\
\text { secondary } \\
\text { qualification }\end{array}$ & $\begin{array}{l}\text { Employed } \\
\text { workforce }\end{array}$ & Unemployed & $\begin{array}{c}\Delta \text { flows to } \\
\text { metropolitan } \\
\text { France }\end{array}$ \\
\hline \multicolumn{7}{|c|}{1975} \\
\hline Guadeloupe & 12.2 & 4.8 & 5.9 & 71.1 & 8.2 & 58 \\
\hline Martinique & 5.1 & 3.5 & 6.4 & 71.4 & 5.4 & 25 \\
\hline Guiana & 9.6 & 5.9 & 7.7 & 79.3 & 5.4 & 34 \\
\hline Réunion & 10.6 & 4.8 & 4.0 & 60.1 & 8.8 & 49 \\
\hline \multicolumn{7}{|c|}{1980} \\
\hline Guadeloupe & 8.1 & 7.3 & 13.4 & 78.8 & 10.9 & 27 \\
\hline Martinique & 2.4 & 7.4 & 15.4 & 81.5 & 12.8 & 25 \\
\hline Guyane & 9.6 & 8.3 & 13.7 & 82.8 & 10.5 & 156 \\
\hline Réunion & 7.6 & 8.4 & 11.6 & 67.5 & 17.1 & 152 \\
\hline \multicolumn{7}{|c|}{1990} \\
\hline Guadeloupe & 3.3 & 7.2 & 24.5 & 84.1 & 22.1 & -43 \\
\hline Martinique & 1.9 & 8.3 & 27.2 & 87.4 & 23.0 & -35 \\
\hline Guiana & 5.0 & 8.0 & 25.0 & 81.2 & 19.4 & -35 \\
\hline Réunion & 4.2 & 7.6 & 18.0 & 75.4 & 27.5 & -26 \\
\hline \multicolumn{7}{|c|}{1999} \\
\hline Guadeloupe & 2.5 & 5.7 & 24.2 & 87.1 & 31.9 & 46 \\
\hline Martinique & 1.7 & 6.0 & 24.2 & 89.2 & 32.4 & 3 \\
\hline Guiana & 2.9 & 8.2 & 24.9 & 80.7 & 27.0 & 50 \\
\hline Réunion & 2.8 & 6.0 & 18.8 & 81.3 & 38.4 & -15 \\
\hline
\end{tabular}


Table A.3. Employment, educational level, and emigration in the DOMs of 46-60-year-olds (\%) at censuses conducted between 1975 and 1999

\begin{tabular}{|c|c|c|c|c|c|c|}
\hline & Farmers & $\begin{array}{c}\text { Those in } \\
\text { higher-level } \\
\text { occupations }\end{array}$ & $\begin{array}{l}\text { Those with } \\
\text { an upper- } \\
\text { secondary } \\
\text { qualification }\end{array}$ & $\begin{array}{l}\text { Employed } \\
\text { workforce }\end{array}$ & Unemployed & $\begin{array}{c}\Delta \text { flows to } \\
\text { metropolitan } \\
\text { France }\end{array}$ \\
\hline \multicolumn{7}{|c|}{1975} \\
\hline Guadeloupe & 23.6 & 3.0 & 2.8 & 63.8 & 6.9 & 82 \\
\hline Martinique & 12.2 & 2.8 & 3.6 & 60.3 & 4.6 & 26 \\
\hline Guiana & 20.1 & 5.3 & 5.2 & 73.0 & 5.4 & -10 \\
\hline Réunion & 17.1 & 3.9 & 2.7 & 49.8 & 6.8 & 126 \\
\hline \multicolumn{7}{|c|}{1982} \\
\hline Guadeloupe & 18.9 & 4.5 & 5.2 & 66.7 & 9.8 & 18 \\
\hline Martinique & 7.8 & 4.4 & 5.8 & 65.8 & 11.0 & 10 \\
\hline Guiana & 15.6 & 7.8 & 9.6 & 76.1 & 7.9 & -16 \\
\hline Réunion & 14.8 & 5.4 & 5.0 & 53.9 & 17.2 & 98 \\
\hline \multicolumn{7}{|c|}{1990} \\
\hline Guadeloupe & 8.3 & 6.2 & 12.7 & 68.3 & 14.8 & -39 \\
\hline Martinique & 4.7 & 6.7 & 14.2 & 70.6 & 15.3 & -42 \\
\hline Guiana & 7.8 & 9.7 & 18.1 & 72.1 & 14.3 & -12 \\
\hline Réunion & 8.7 & 7.1 & 8.8 & 55.4 & 23.1 & -35 \\
\hline \multicolumn{7}{|c|}{1999} \\
\hline Guadeloupe & 4.5 & 8.2 & 19.7 & 72.6 & 21.4 & -17 \\
\hline Martinique & 2.6 & 9.3 & 20.7 & 75.5 & 19.2 & -7 \\
\hline Guiana & 4.1 & 12.0 & 22.3 & 74.8 & 21.6 & 20 \\
\hline Réunion & 4.8 & 10.3 & 16.0 & 63.7 & 28.4 & -42 \\
\hline
\end{tabular}


Table A.4. Odds ratios comparing the education of overseas citizens who moved to metropolitan France between two censuses against that of those living in their DOM of origin

\begin{tabular}{|c|c|c|c|}
\hline Year & $\begin{array}{l}\text { With at least a CAP } \\
\text { (aged 18-27) }\end{array}$ & $\begin{array}{c}\text { With at least } \\
\text { an upper-secondary } \\
\text { qualification (aged 18-27) }\end{array}$ & $\begin{array}{l}\text { Continuing education } \\
\text { for those with } \\
\text { an upper-secondary } \\
\text { qualification (aged 18-27) }\end{array}$ \\
\hline \multicolumn{4}{|c|}{ Guadeloupe } \\
\hline 1975 & 3.0 & 2.0 & 4.8 \\
\hline 1982 & 4.4 & 3.3 & 3.1 \\
\hline 1990 & 3.1 & 3.4 & 1.7 \\
\hline 1999 & 3.7 & 2.8 & 2.2 \\
\hline \multicolumn{4}{|c|}{ Guiana } \\
\hline 1975 & 3.5 & 4.2 & 6.3 \\
\hline 1982 & 4.3 & 4.0 & 11.3 \\
\hline 1990 & 4.3 & 4.6 & 6.2 \\
\hline 1999 & 2.2 & 2.4 & 5.3 \\
\hline \multicolumn{4}{|c|}{ Martinique } \\
\hline 1975 & 3.7 & 2.5 & 2.4 \\
\hline 1982 & 4.1 & 3.4 & 2.9 \\
\hline 1990 & 2.4 & 2.7 & 1.7 \\
\hline 1999 & 3.9 & 4.3 & 3.0 \\
\hline \multicolumn{4}{|c|}{ Réunion } \\
\hline 1975 & 4.8 & 3.1 & 4.6 \\
\hline 1982 & 5.3 & 2.5 & 2.4 \\
\hline 1990 & 3.3 & 2.8 & 1.3 \\
\hline 1999 & 3.4 & 2.5 & 1.7 \\
\hline
\end{tabular}




\section{REFERENCES}

ANSELIN Alain, 1990, Lémigration antillaise en France: la troisième île, Paris, Karthala, $304 \mathrm{p}$.

BRUTEL Chantal, 2014, "Estimer les flux d'entrées sur le territoire à partir des enquêtes annuelles de recensement", Working paper F1403, INSEE, 24 p.

CARON Louise, 2018, "Whose integration? Immigrants' emigration and the measurement of labour market integration in France", Population, English Edition, 73(3), forthcoming.

CHILDERS Kristen Stromberg, 2009, "Departmentalization, migration, and the politics of the family in the post-war French Caribbean", The History of the Family, 14(2), pp. 177-190.

CONDON Stéphanie A., OGDEN Philip E., 1991a, "Afro-Caribbean migrants in France: employment, state policy and the migration process", Transactions of the Institute of British Geographers, 16(4), pp. 440-457.

Condon Stéphanie A., OGDEN Philip E., 1991b, "Emigration from the French Caribbean: The origins of an organized migration", International Journal of Urban and Regional Research, 15(4), pp. 505-523.

CONDON Stéphanie A., 2008, "Travail et genre dans l'histoire des migrations antillaises", Travail, genre et sociétés, 20(2), pp. 67-86.

CONSTANT Fred, 1987, "La politique française de l'immigration antillaise de 1946 à 1987", Revue européenne de migrations internationales, 3(3), pp. 9-30.

CRUSOL Jean, 1975, "Quelques aspects économiques de la départementalisation aux Antilles françaises", Caribbean Studies, 15(1), pp. 20-31.

CUEUGNIET Chantal, 1991, "La population des DOM en 1990", Économie et statistique, 248(1), pp. 3-18.

DAILY Andrew M., 2014, "Race, citizenship, and Antillean student activism in postwar France, 1946-1968", French Historical Studies, 37(2), pp. 331-357.

DomenaCH Hervé, GUENGANT Jean-Pierre, 1981, "Chômage et sous-emploi dans les DOM", Économie et statistique, 137(1), pp. 3-23.

DOMENACH Hervé, PiCOUET Michel, 1988, Dynamique de la population et migration en Guyane, La Nature et l'homme, Cayenne, Centre ORSTOM de Cayenne, 53 p.

Domenach Hervé, Picouet Michel, 1992, La Dimension migratoire des Antilles, Paris, Economica, $254 \mathrm{p}$.

Dumont Jacques, 2010, "La quête de l'égalité aux Antilles: la départementalisation et les manifestations des années 1950", Le Mouvement social, 230(1), pp. 79-98.

FELICIANO Cynthia, 2005, "Educational selectivity in U.S. immigration: how do immigrants compare to those left behind?", Demography, 42(1), pp. 131-152.

FRANCE. NATIONAl CONSTITUENT ASSEMBLy, 1946, "Loi no 46-451 du 19 mars 1946 tendant au classement comme départements français de la Guadeloupe, de la Martinique, de la Réunion et de la Guyane française".

GIVORD Pauline, 2014, "Méthodes économétriques pour l'évaluation de politiques publiques", Économie \& prévision, 204-205(1), pp. 1-28. 
GUYON Stéphanie, 2016, "Trajectoires post-coloniales de l'assimilation", Politix, 116(4), pp. 9-28.

ICHOU Mathieu, 2014, "Who they were there: immigrants' educational selectivity and their children's educational attainment", European Sociological Review, 30(6), pp. 750-765.

MAISON Dominique, Millet Elisabeth, 1974, "Les départements et territoires d'outre-mer", Population, 29(2), pp. 327-356.

MARIE Claude-Valentin, GIRAUD Michel, 1987, "Insertion et gestion sociopolitique de l'identité culturelle: le cas des Antillais en France", Revue européenne des migrations internationales, 3(3), pp. 31-48.

MARIE Claude-Valentin, RALLU Jean-Louis, 2004, "Migrations croisées entre DOM et Métropole: l'emploi comme moteur de la migration", Espace populations sociétés, 2, pp. 237-252.

Massey Douglas S., ArAngo Joaquin, Hugo Graeme, KouAOuCi Ali, Pellegrino Adela, TAYLOR J. Edward, 1993, "Theories of international migration: A review and appraisal", Population and Development Review, 19(3), pp. 431-466.

PATTIEU Sylvain, 2016, "Un traitement spécifique des migrations d'outre-mer: le BUMIDOM (1963-1982) et ses ambiguïtés", Politix, 116(4), pp. 81-113.

PIORE Michael J., 1979, Birds of Passage: Migrant Labor and Industrial Societies, Cambridge, Cambridge University Press, 229 p.

POURCHEz Laurence, 2014, "Métissage, multi-appartenance, créolité à l'île de La Réunion", Anthropologie et société, 38(2), pp. 45-66.

RALLU Jean-Louis, 1998, "Les catégories statistiques utilisées dans les DOM-TOM depuis le début de la présence française", Population, 53(3), pp. 589-608.

RALLU Jean-Louis, DiAgNE Andel, 2005, "La population des départements d'outremer depuis les années 1950", in Christophe Bergouignan, Chantal Blayo, et al. (eds.), La population de la France: évolutions démographiques depuis 1946, vol.1, Paris, Ined, pp. 103-128.

Rosenbaum Paul R., Rubin Donald B., 1983, "The central role of the propensity score in observational studies for causal effects", Biometrika, 70(1), pp. 41-55.

SOLIGNAC Matthieu, 2016, "Lémigration des immigrés, une dimension oubliée de la mobilité géographique", Working paper, halshs-01422323, 39 p.

STORA Benjamin, 2016, "Commission d'information et de recherche historique sur les événements de décembre 1959 en Martinique, de juin 1962 en Guadeloupe et en Guyane, et de mai 1967 en Guadeloupe: rapport à Madame la ministre des Outre-mer", Paris, Ministère des Outre-mer, 100 p.

TEMPORAL Franck, 2011, "Migrations et emplois à l'île de La Réunion”, Revue européenne des migrations internationales, 27(3), pp. 131-164.

Temporal Franck, MARiE Claude-Valentin, Bernard Stéphane, 2011, "Labour market integration of young people from the French overseas départements: at home or in metropolitan France?", Population, English Edition, 66(3), pp. 473-517.

VERGÈS Françoise, 2017, Le Ventre des femmes: Capitalisme, racialisation, féminisme, Paris, Albin Michel, 230 p.

WATERS Mary C., 2001, Black Identities: West Indian Immigrant Dreams and American Realities, Cambridge, Mass., Harvard University Press, 432 p.

WIDMER Isabelle, 1999, "Migrations, emploi, développement: analyse comparée de l'île de La Réunion et de l'île Maurice", doctoral thesis, Université Paris 1.

ZOLBERG Aristide R., 1999, "Matters of state: theorizing immigration policy", in Hirschman Charles, Kasinitz Philip, DeWind Joshua (eds.), The Handbook of International Migration: The American Experience, New York, Russell Sage Foundation, pp. 71-93. 


\section{Marine Haddad • Migration from French OVerseas Departments to Metropolitan France: What We Can learn about a State Policy from the Censuses, 1962-1999}

This article offers new perspectives for demographic analysis of four French overseas départements (DOM): Guadeloupe, French Guiana, Martinique, and Réunion. What are the effects of public population policies, notably those implemented by the Office for DOM migration (Bureau pour la migration des DOM, Bumidom, 1963-1981) on migration to metropolitan France? French census data from 1968 to 1999 are used to measure the size and structure of migration flows over time, as well as their scale, expressed as a proportion of the DOM populations. Using difference-in-difference regressions, this study assesses the effects of the policies implemented by the Bumidom. It shows that while the Bumidom accelerated the growth of migration flows, they were also fuelled by the socioeconomic gap between the DOMs and metropolitan France. Given that places in higher education and the share of high school graduates in the DOMs do not increase at the same pace as in metropolitan France, the rise of educational aspirations also appears to be a push factor. A comparison of DOM residents remaining at home and those who migrate to metropolitan France shows that since 1968 the latter have been characterized by a higher level of education.

\section{Marine HADDAD • L'EFFET D'UNE POLITIQUE D'ÉTAT SUR LES MIGRATIONS \\ DOM-MÉTROPOLE. LES ENSEIGNEMENTS DES RECENSEMENTS DE 1962 À 1999}

Cet article propose de nouvelles perspectives d'analyse de la démographie de quatre départements français d'outre-mer (DOM : Guadeloupe, Guyane, Martinique et La Réunion). Quels sont les effets des politiques publiques de population, portées notamment par le Bureau pour la migration des DOM (Bumidom, 1963-1981) et ses successeurs, sur les migrations vers la métropole ? Les recensements de 1968 à 1999 permettent de mesurer l'ampleur et la structure de ces flux migratoires au cours du temps, ainsi que leur poids dans la population des natifs des DOM. S'appuyant sur des régressions en différences de différences, cette analyse permet de mesurer l'effet des politiques menées par le Bumidom. Elle montre que cet organisme a favorisé la croissance des migrations, également alimentées par les inégalités socioéconomiques entre les DOM et la métropole. Alors que l'offre d'enseignement supérieur dans les DOM et la part de bacheliers ne progressent pas au même rythme, les aspirations scolaires peuvent également être motrices des migrations. La comparaison des ultramarins restés dans les DOM avec ceux partis en métropole révèle que, depuis 1968, ces derniers sont caractérisés par un niveau d'études plus élevé.

\section{Marine HAdDAD • EL EFECTO DE UNA POLÍtICA DE ESTAdo SOBRE LAS MIGRACIONES DOM-METRÓPOLI. LAS ENSEÑANZAS DE LOS CENSOS DE 1962 A 1999.}

Este artículo propone nuevas perspectivas de análisis de la demografía de cuatro departamentos franceses de ultramar (DOM: Guadalupe, Guyana, Martinica y Reunión) ¿Cuáles son les efectos de las políticas públicas de población conducidas en particular por el Bureau pour les migrations des DOM (Bumidom, 1963-1981) y sus sucesores, sobre las migraciones hacia la metrópoli? Los censos de 1968 a 1999 permiten medir la amplitud y la estructura de estas migraciones a lo largo del tiempo, así como su peso en la población de los nativos de los DOM. El análisis muestra que el Bumidom ha incrementado las migraciones, alimentadas también por las desigualdades socio-económicas entre los DOM y la metrópoli. En la medida en que la oferta de enseñanza superior en los DOM no ha crecido al mismo ritmo que la parte de bachilleres, las aspiraciones escolares pueden también haber favorecido la migración. La comparación entre los habitantes que se han quedado en los DOM y los que han migrado hacia la metrópoli revela que, desde 1968, estos últimos se caracterizan por un nivel de estudios más elevado.

Keywords: migration, overseas department, Bumidom, difference-in-differences, census, longitudinal analysis

Translated by Beatrice van Hoorn Alkema 
